\title{
Treating the dysfunctional placenta
}

\section{Colin P Sibley ${ }^{1,2}$}

${ }^{1}$ Maternal and Fetal Health Research Centre, Division of Developmental Biology and Medicine, School of Medical Sciences, Faculty of Biology, Medicine and Health, University of Manchester, Manchester, UK 2St Mary's Hospital, Central Manchester University Hospitals NHS Foundation Trust, Manchester Academic Health Science Centre, Manchester, UK
Correspondence should be addressed to C P Sibley

Email

colin.sibley@manchester.ac. uk

\begin{abstract}
Placental dysfunction underlies major obstetric diseases such as pre-eclampsia and fetal growth restriction (FGR). Whilst there has been a little progress in prophylaxis, there are still no treatments for placental dysfunction in normal obstetric practice. However, a combination of increasingly well-described in vitro systems for studying the human placenta, together with the availability of more appropriate animal models of preeclampsia and FGR, has facilitated a recent surge in work aimed at repurposing drugs and therapies, developed for other conditions, as treatments for placental dysfunction. This review: (1) highlights potential candidate drug targets in the placenta - effectors of improved uteroplacental blood flow, anti-oxidants, heme oxygenase induction, inhibition of HIF, induction of cholesterol synthesis pathways, increasing insulinlike growth factor II availability; (2) proposes an experimental pathway for taking a potential drug or treatment for placental dysfunction from concept through to early phase clinical trials, utilizing techniques for studying the human placenta in vitro and small animal models, particularly the mouse, for in vivo studies; (3) describes the data underpinning sildenafil citrate and adenovirus expressing vascular endothelial growth as potential treatments for placental dysfunction and summarizes recent research on other potential treatments. The importance of sharing information from such studies even when no effect is found, or there is an adverse outcome, is highlighted. Finally, the use of adenoviral vectors or nanoparticle carriers coated with homing peptides to selectively target drugs to the placenta is highlighted: such delivery systems could improve efficacy and reduce the side effects of treating the dysfunctional placenta.
\end{abstract}

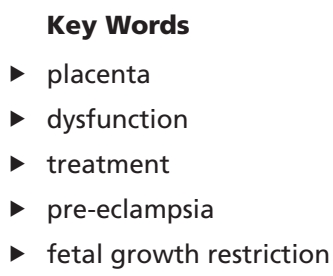

Journal of Endocrinology (2017) 234, R81-R97

\section{Introduction}

By the end of pregnancy the human placenta is the largest endocrine organ in a woman, secreting large quantities of an array of hormones into both maternal and fetal plasma (Costa 2016). These hormones control maternal adaptation to pregnancy, the timing of parturition, matching of supply with demand for nutrients by the fetus to enable normal growth (Sferruzzi-Perri \& Camm 2016) and indeed control of placental development itself. It is therefore not surprising that defective placentation and the consequently dysfunctional placenta is a direct cause of what has been termed the 'Great Obstetrical Syndromes': pre-eclampsia, fetal growth restriction (FGR), preterm labour, preterm premature rupture of membranes, late spontaneous abortion and abruption placentae (Brosens et al. 2011). This involvement of the placenta in pregnancy complications now seems self-evident, and is indeed inherent in the old-fashioned obstetric phrase 'placental insufficiency'. However, the focus of obstetric intervention for these conditions has been managing the outcomes (e.g. delaying labour or inducing labour). 
In fact, there have been very few therapeutic advances in obstetrics in the last 30 years (Fisk \& Atun 2008, Chappell \& David 2016). Whilst aspirin prophylaxis for women at high-risk pre-eclampsia, for example, is now a recommendation (https://www.nice.org.uk/ guidance/qs35/chapter/quality-statement-2-antenatalassessment-of-pre-eclampsia-risk), it is only recently that researchers have considered the possibility of treating the dysfunctional placenta itself. This review focuses on treating the dysfunctional placenta in pre-eclampsia and FGR. It will consider: the pathophysiology of these pregnancy complications and candidate drug targets; why there are currently no treatments for placental dysfunction in general obstetric practice and pre-clinical strategies and models for developing such treatments; potential treatments for placental dysfunction arising from recent research; and finally, future opportunities and challenges to this emerging field of research will be considered.

\section{Pathophysiology of pre-eclampsia and FGR and therapeutic targets}

The signs of pre-eclampsia are maternal hypertension with endothelial and renal dysfunction; in extreme cases, or if not treated, pre-eclampsia may progress to eclampsia with cerebral oedema, epileptic fits and death (Duley 2009). Pre-eclampsia remains the major cause of death of pregnant women worldwide with over 50,000 deaths per annum (Duley 2009). FGR is defined as a failure of the fetus to reach its genetic growth potential; its diagnosis is complicated by the difficulty in separating the normal small fetus from the truly growth-restricted one (Baschat \& Galan 2017). Although beyond the scope of this review, it seems likely that diagnosis of placental dysfunction will eventually be a better diagnostic indicator of FGR than is fetal size or growth trajectory (Benton et al. 2016). FGR is strongly associated with stillbirth and neurodevelopmental disorders in the survivors (Flenady et al. 2011, Baschat \& Galan 2017). Around 50\% of stillbirths are associated with FGR, and such deaths still occur in 1/200 pregnancies with massive socio-economic consequences (Flenady et al. 2011, Heazell et al. 2016). FGR and pre-eclampsia frequently occur together.

The origins of the placental dysfunction underlying pre-eclampsia and FGR (as well as the other Great Obstetric Syndromes) are predominantly in abnormal physiological conversion of the spiral arteries in the endometrium supplying blood to the intervillous (maternal) blood space (IVS) of the placenta (Brosens et al. 2011). In normal pregnancy, following the formation of the placenta extravillous cytotrophoblast (EVT) cells invade the spiral arteries so that both the endothelium and smooth muscle of the vessels are eroded (Burton et al. 2017). This invasion by the EVT is extensive and initially plugs the terminal end of the vessels, preventing any blood flow into the intervillous space until about week 10 when the plug becomes disrupted. The invasion also results in the distal end of the spiral arteries becoming converted from small calibre vessels, with normal vasoreactivity, into wide conduits. The proximal ends of the spiral arteries are not converted by EVT but do dilate during early pregnancy, as do other parts of the uterine vasculature, most likely under the influence of oestrogen. The consequent fall in resistance enables an increase in blood flow to the uterus from about $45 \mathrm{~mL} / \mathrm{min}$ pre-pregnancy to $750 \mathrm{~mL} /$ min during pregnancy. At the same time, the dilation of the terminal ends of the spiral arteries probably ensures that blood flow into the IVS is relatively slow, and nonturbulent, helping to prevent damage to the villous tree and facilitating diffusional exchange across the placenta.

Pre-eclampsia and FGR are associated with failure in EVT invasion and consequent malformation of the maternal circulation of the placenta (Brosens et al. 2011, Burton et al. 2017). Physiological conversion is restricted to the superficial endometrial parts of the spiral arteries or does not happen at all. Consequently: (i) with no distal dilation, maternal blood will enter the IVS at greater speed disrupting the villous tree, with formation of intervillous blood lakes, thrombosis and fibrin, which will affect nutrient exchange processes; (ii) the spiral arteries will maintain a greater than normal ability to vasodilate and vasoconstrict, causing massive oxidative and nitrative stress in the placenta through ischaemia-reperfusion processes and (iii) there may be atherosclerotic changes in the distal ends of the arteries further altering blood flow to the IVS. These abnormalities in spiral artery re-modelling therefore lead to the poor uteroplacental blood flow, which compromises the formation of the fetoplacental circulation and villous tree of the placenta with the consequent dysfunction underlying pre-eclampsia and FGR (Fig. 1). In pre-eclampsia, it is proposed that hypoxia and/or ischaemia-reperfusion lead to the release of free radicals and inflammatory mediators causing cellular stress in the syncytiotrophoblast (the placental epithelium) (Powe et al. 2011, Burton et al. 2017). This leads to the release of abnormal levels of factors into the maternal circulation, which causes an exaggerated inflammatory response and defective proliferation and survival of endothelial cells resulting

Published by Bioscientifica Ltd. 
A

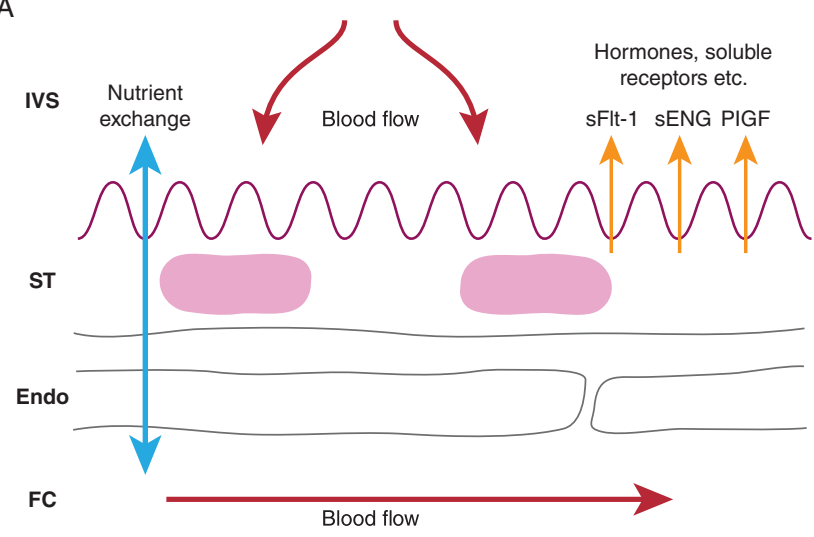

B

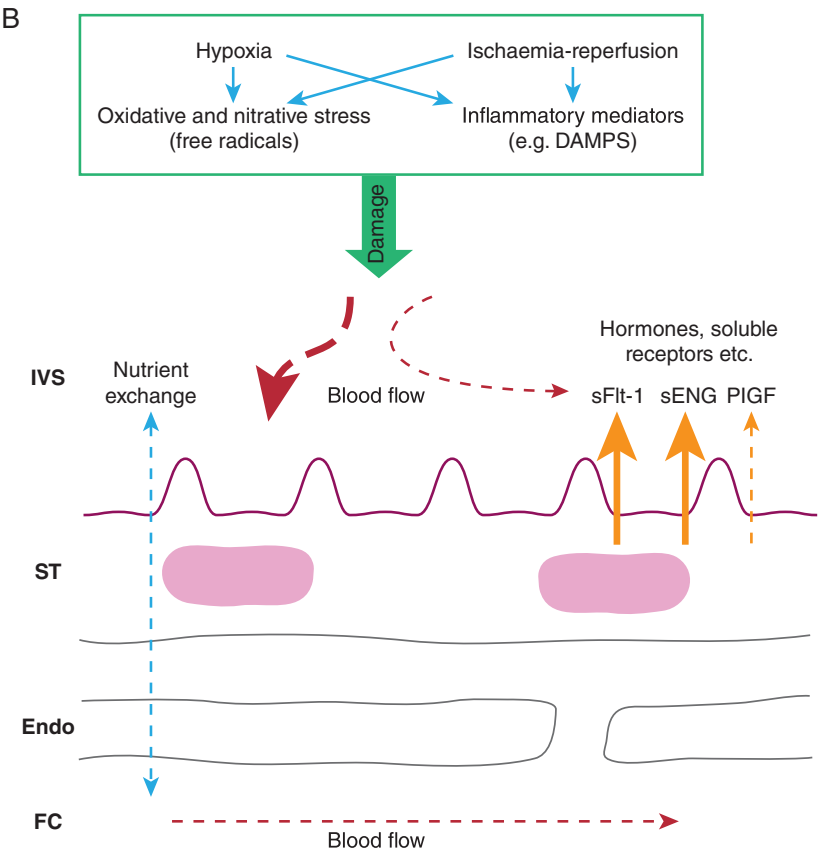

Figure 1

(A) Image showing the main structural and functional elements of the exchange barrier of the normal placenta: IVS intervillous space with maternal blood; ST syncytiotrophoblast - the placental epithelium; Endo fetal capillary endothelium; FC fetal capillary with fetal blood. (B) Consequences of abnormal spiral artery invasion and conversion on the structure and function of the placenta. Hypoxia and ischaemia-reperfusion may lead to the formation of free radicals and/or inflammatory mediators such as damage-associated molecular patterns (DAMPS). These could cause: abnormal blood flow patterns in the IVS; decreased fetoplacental blood flow; altered structure of the exchange barrier (e.g. reduced surface area and increased thickness of the ST) with reduced nutrient transfer; increases and decreases in secretion of hormones, soluble receptors and other placental proteins and factors. All of these are potential targets for treatments of placental dysfunction.

in endothelial and, more specifically, renal dysfunction. These placental factors include excess release of soluble fms-like tyrosine kinase 1 (sFlt-1) and soluble Endoglin (sENG) which sequester circulating vascular endothelial growth factor (VEGF) and placental growth factor (PIGF), reducing the free concentrations of these hormones in maternal plasma, and transforming growth factor $\beta$ (TGF $\beta$ ), as well as reducing the secretion of PIGF from the placenta (Powe et al. 2011, Burton et al. 2017). The direct cause of FGR is a failure of adequate nutrient supply via the placenta, arising from poor blood flow to and from the placenta and/or defects in exchange processes due to reduced surface area of the syncytiotrophoblast or of reduced activity of nutrient transporter proteins in this transporting epithelium (Desforges \& Sibley 2010). These structural and functional changes following abnormal spiral artery conversion and remodelling provide potential targets for treating placental dysfunction (Fig. 1).

Although the origins of pre-eclampsia and FGR reside in abnormal placental development in early pregnancy, onset of both conditions can be in early or later gestation. Onset in the third trimester may be a delayed consequence of the failures of placental development in early pregnancy, for example, a failure of the capacity of a maldeveloped placenta to supply nutrients to the rapidly growing fetus in mid-to-late pregnancy, or of a separate insult such as an infection. Recent data suggest that placental inflammation occurring in late pregnancy, with either infectious or non-infectious origins, could lead to placental dysfunction (Nadeau-Vallée et al. 2016, Brien et al. 2017).

Reviewing this knowledge of the pathophysiology of pre-eclampsia and FGR suggests several possible therapeutic targets for the treatment of placental dysfunction (Fig. 1). Obviously, the most effective target would be the EVT and improving invasion into the spiral arteries where this appears to be defective. However, it is impossible at present to detect a failure in this process, occurring as it does right at the start of pregnancy, and the secondary pathologies are more amenable to treatment: improving uteroplacental and fetoplacental blood flow, combating oxidative and nitrative stress, reducing placental inflammation, reducing placental production of sFlt-1 and sEng from the pre-eclamptic placenta and stimulating placental and fetal growth. Recent work on such potential treatments is reviewed below. However, it 
is important first to consider the most appropriate preclinical strategies for testing potential treatments.

\section{Pre-clinical strategies for testing potential therapeutic treatments of placental dysfunction}

Bearing in mind the burden of disease caused by preeclampsia and FGR, it may be reasonably asked why there have been so few advances in therapeutic options available to the obstetrician over the last 30 years or so and why there are so few clinical trials in this area (Fisk \& Atun 2008, Chappell \& David 2016). The main reason is probably the difficulty of developing drugs for conditions where there are two people involved, mother and fetus, and the consequent increased risk of side effects. This is epitomized by the thalidomide tragedy of 50-60 years ago; this drug, given as a treatment for women with hyperemesis in early pregnancy, had massive teratogenic side effects (Franks et al. 2004). This undoubtedly made the pharmaceutical industry even less likely to invest the large sums of money required in developing treatments for pregnancy complications. However, a secondary reason has been the absence of really well-defined strategies for good pre-clinical testing of drugs for preeclampsia and FGR. Broadly, three options are available: animal models, use of human placental tissue in vitro and mathematical modelling.

Animal models of pre-eclampsia have been recently reviewed in McCarthy et al. (2011), Erlandsson et al. (2016) and those of FGR by Swanson \& David (2015). These animal models range in size from mice to sheep and pigs, and include animals spontaneously showing disease symptoms, and those arising from surgical, nutritional, pharmacological and genetic manipulations to induce pre-eclampsia and/or FGR. All have advantages and disadvantages: for example, the mouse has a placenta which is haemotrichorial (three trophoblast layers, one directly bathed in maternal blood) and so similar, though not identical, to the haemomonochorial human placenta (one trophoblast layer), can be genetically manipulated relatively easily (Dilworth \& Sibley 2013) and is fairly low cost. The guinea pig is more expensive but has a haemomonochorial placenta very similar to human; the larger size of the sheep makes surgical intervention and direct access to both sides of the placenta quite straightforward, but its placenta is very different to the human, being epitheliochorial with maternal endothelium as well as trophoblast in the barrier (Swanson \& David 2015).

The ideal animal model of pre-eclampsia would have similar pathology to the defective invasion by EVT of the spiral arteries found in women and would have the symptoms of pregnancy-induced maternal hypertension, renal and endothelial dysfunction and excess circulating sFlt-1 and sEng. Whilst several models show some or all of the latter symptoms, there have been virtually no reports of models with defective invasion. This is because of the major differences in placentation between species, with few showing the deep invasion by EVT found in women. Even when there are maternal symptoms, a common drawback is that these symptoms are not pregnancy specific, such as the hypertension found in the endothelial nitric oxide (eNOS) knockout mouse (Huang et al. 1995, Hefler et al. 2001, Kusinski et al. 2012). A very valuable exception may be the Storkhead box 1 (STOX1) transgenic mouse (Doridot et al. 2013). STOX1 is a transcription factor associated with human pre-eclampsia, and its overexpression in a choriocarcinoma cell lines leads to similar transcriptional changes as found in the human disease. The STOX1 transgenic mouse shows gestational hypertension, proteinuria and raised levels of sFlt- 1 and sENG; it is therefore probably the most complete animal model of human pre-eclampsia described to date.

The ideal animal model of FGR would also have defective invasion of maternal arteries, and signs of a dysfunctional placenta being followed in gestation by true FGR i.e. not just a normally small fetus; there may also be maternal hypertension mimicking the pre-eclampsia with FGR found in women. In practice, no current models show the primary defect of abnormal invasion, though several show the symptoms. In our laboratory, we have found genetic mouse models of FGR to be particularly useful for testing potential therapies, for the reasons mentioned earlier (relatively cheap, similar though not identical placenta to human) and in particular the comparable cardiovascular adaptations to pregnancy and placental physiology in mice and women (Dilworth \& Sibley 2013). Furthermore, the short gestation (19 days) of this species allows statistically appropriate numbers of animals to be studied quite rapidly. Development of mouse fetal weight distribution charts has helped us define FGR similarly to obstetric diagnoses (Dilworth et al. 2011).

We have found parallel use of the eNOS- ${ }^{-}$and placental-specific insulin-like growth factor 2 (Igf2) knockout mice to be particularly valuable in assessing therapies for FGR. The former have fetuses with an http://joe.endocrinology-journals.org DOI: $10.1530 / J O E-17-0185$ (c) 2017 The author Printed in Great Britain
Published by Bioscientifica Ltd 
average $10 \%$ lower weight at term compared to wildtype (WT) mice with $32 \%$ falling below the 5 th centile of WT weights (Kusinski et al. 2012). eNOS-/- mouse uterine arteries have dysfunctional responses to agonists in vitro and the placentas show reduced activity of the System A amino acid transporter, both symptomatic of the placental phenotype in human FGR (Sibley et al. 2005, Kusinski et al. 2012). Furthermore, spiral artery remodelling and fetoplacental vascular development are impaired in eNOS-/- vs WT mice, in common with human FGR (Kulandavelu et al. 2012, 2013). The latter is associated with reduced expression of VEGF, a key promoter of placental vasculogenesis/angiogenesis (Kulandavelu et al. 2013).

The placental-specific Igf2 knockout (P0) mouse fetus has a reduction in weight of $20-25 \%$ compared to its WT littermates with 95\% falling below the 5th centile of WT weights (Constância et al. 2002, Dilworth et al. 2010). P0 placental weight is reduced compared to WT from about embryonic day 14 (E14) onwards and so precedes the onset of FGR (Constância et al. 2002, 2005). System A amino acid transporter activity in P0 placentas first increases vs WT at E16, probably as an adaptive response to the lower placental weight, but then decreases close to term (Constância et al. 2002, 2005), so that the overall capacity of the small P0 placenta to transport System A amino acid substrates is reduced. The morphology of the P0 placenta is also abnormal: stereology shows that the surface area of the trophoblast layers is lower compared to WT and the thickness is increased, in common with the human FGR placenta, resulting in a reduction in the diffusional permeability (Sibley et al. 2004). However, uterine arteries from the $\mathrm{P} 0$ mouse show normal reactivity when challenged with agonists, unlike the eNOS ${ }^{-/-}$mouse (Kusinski et al. 2011). Therefore, these two mouse models of FGR have differences in placental phenotype, which might relate to subgroups of the disease in women, and allow us to test both the general efficacy of particular drugs and obtain information on whether they are primarily acting on vascular or non-vascular targets or both (Dilworth et al. 2013).

One of the boons of studying the human placenta is the availability, with appropriate ethical consent, of large amounts of the organ which can be studied in vitro. Three different in vitro model systems have been developed, with increasing cellular complexity, for studies focused on the trophoblast. First, cytotrophoblast cells, the progenitor cells of the syncytiotrophoblast, can be isolated from the human placenta, delivered at any point in gestation (Kliman et al. 1986). These cytotrophoblast cells differentiate over the first $48 \mathrm{~h}$ in culture and multinucleate to form syncytiotrophoblast-like islands (Kliman et al. 1986). They can therefore be used to study specific effects of therapies on the syncytiotrophoblast. Secondly, placental explants are small $\left(3 \mathrm{~mm}^{3}\right)$ fragments of tissue dissected from the villous tree. These can be studied in either short-term or long-term (7 days or so) culture and have the advantage of retaining the normal architecture of the placental exchange barrier with all the cell types normally present (Simán et al. 2001, Greenwood \& Sibley 2006). Finally, intact cotyledons, or segments, of the placenta, delivered at term can be perfused with physiological solution through the maternal and fetal circulations (Schneider et al. 1972, Brownbill et al. 1995). This is therefore the model that most similarly replicates the in vivo placenta with architecture intact and circulatory flow. All of these systems can be used to study placentas from both normal pregnancies and those with dysfunction associated with pre-eclampsia and FGR. Together, these three preparations are excellent for studying modes of action of particular therapies, whether they work on both normal and abnormal placentas, for studying toxicity in the most appropriate human tissue and, in the case of the perfused cotyledon, investigating pharmacokinetics of maternofetal drug transfer. However, they of course cannot provide any information of effects on the ultimate clinical systemic endpoints such as hypertension or fetal growth; only animal models can at present provide such essential pre-clinical information.

Although these trophoblast focused on in vitro systems, it is also possible to use isolated myometrial and chorionic plate arteries, dissected from myometrial biopsies taken at the time of Caesarean section or from the delivered placenta, respectively, from women having normal or complicated pregnancies, for studies on vascular reactivity (Wareing et al. 2002, 2004). Wire/ pressure myography allows the tension generated by the change in diameter of these arteries to be measured in the presence and absence of any drug or agent of interest. Human umbilical vein endothelial cells (HUVECs) are relatively easily isolated, are commercially available and are widely used as a model of systemic endothelial cells; microvascular endothelial cells may also be isolated from the placenta (Jones et al. 2015). Tong and coworkers (see references in Table 1) reported a useful strategy in a series of papers investigating drugs that might reduce sFlt-1 and sENG production, and so be useful in pre-eclampsia, using a combination of isolated primary cytotrophoblast http://joe.endocrinology-journals.org

DOI: $10.1530 / J O E-17-0185$
() 2017 The author Printed in Great Britain
Published by Bioscientifica Ltd 
cells, placental explants and HUVECs. This combination allowed effects on the primary endpoint (sFlt- 1 and sENG secretion) to be measured and mechanisms of action to be examined, as well as determining, using the HUVECs as a model of endothelial cells, whether dysfunctionality as found in pre-eclampsia could be corrected.

Mathematical, in silico, modelling of the human placenta is still in its infancy, but studies show that it has great promise for investigating and shedding new light on complex issues such as amino acid transfer across the placenta and determinants of blood flow in the intervillous space (Widdows et al. 2015, Panitchob et al. 2016). As these models develop, they will provide means of rapidly screening potential therapies and information for focusing in vitro work.

In summary, whilst there is no single ideal pre-clinical model, there are extremely well-characterized animal and in vitro systems which, used in combination, are excellent tools for determining the effectiveness of potential treatments of placental dysfunction. An experimental pipeline for taking a potential drug or treatment for placental dysfunction from concept through to early phase clinical trials is shown in Fig. 2. This provides a starting point for debate on the ideal pathway. One area for discussion is on the usefulness of non-human primates in these studies. They are not included in Fig. 2 because of their expense, the technical challenges involved in their use and the ethical sensitivity, all of which require work to be done in specialist centres. On the other hand, they could accelerate translation and possibly reduce the need for some early phase clinical trials.

\section{Potential treatments for placental dysfunction emerging from pre-clinical studies}

For the reasons already described, there are no drugs being developed by the pharmaceutical industry to specifically treat placental dysfunction. Therefore, the broad strategy recently used by a number of groups working in this area is to identify drugs: (1) that have been developed to treat other diseases but which target pathways that could be useful in placental dysfunction e.g. vasodilators, oxygen/ nitrogen free radical scavengers; (2) for which there is at least some pre-existing evidence for safety in pregnancy. Identified drugs have then been tested using a mix of the pre-clinical models reviewed above. Sildenafil citrate provides a good example of where this kind of strategy has been applied with contributions from a number of different laboratories over a number of years. Adenovirusmediated delivery of VEGF provides a good example of a somewhat different strategy with a more systematic approach being taken by a single group of researchers to the pre-clinical development of a treatment to increase uteroplacental blood flow. These two examples are considered in more detail below, whilst Table 1 provides a summary of substances that have been tested so far as potential direct treatments of placental dysfunction.

\section{Sildenafil citrate (Viagra) as a treatment for placental dysfunction}

Sildenafil citrate (SC) is a phopshodiesterase-5 inhibitor which blocks the breakdown of cGMP and so enhances nitric oxide (NO)-mediated vasodilation. Therefore, although designed as a treatment for pulmonary hypertension and later used successfully to treat erectile dysfunction in men, SC could be useful to improve perfusion through the uteroplacental circulation. A systematic review of a small number of clinical and animal pregnancy studies in 2007 suggested that SC had no teratogenic or other adverse effects in animals or women (Villanueva-García et al. 2007) and so the drug fits the criteria for a potential treatment of FGR. With this in mind, Wareing and coworkers (Wareing et al. 2005) investigated whether SC would improve vasodilation in small myometrial arteries mounted in the wire myograph. They found that vessels from FGR placentas showed increased artery vasoconstriction and decreased endothelial-dependent vasodilation as compared to those from normal placentas and that both these effects were reversed by SC. This encouraged further pre-clinical studies of the drug.

Disappointingly, and of concern, a sheep model of FGR produced by single umbilical artery ligation (Miller et al. 2009) found that SC administered as a $100 \mathrm{mg}$ bolus after $24-\mathrm{h}$ infusion $(4.17 \mathrm{mg} / \mathrm{h})$ at around day 115 of gestation (term in sheep is 150 days) had no effect on uterine blood flow, and in fact increased fetal heart rate. The reasons for these unexpected effects of SC were not clear. A negative effect of SC on pup weight was also found in a rat model where FGR was induced by administration of N $\omega$-nitro-Larginine methyl ester (1-NAME), a blocker of nitric oxide synthase, by gavage from days 14 to 19 of gestation (term in the rat is days 21); SC administration via the same route actually reduced pup weight greater than l-NAME alone (Nassar et al. 2012). Clearly gavage is not a clinically relevant route of administration. http://joe.endocrinology-journals.org DOI: $10.1530 / J O E-17-0185$
() 2017 The author Printed in Great Britain
Published by Bioscientifica Ltd 
By contrast, in another sheep study, this time using nutrient restriction to induce FGR, Satterfield and coworkers (Satterfield et al. 2010) found that SC, administered as a daily subcutaneous injection from 28 to 115 days gestation at a maximum of $150 \mathrm{mg} /$ day, improved both fetal weight and amino acid availability; no blood flow measurements were reported. The disparity between the two sheep studies obviously could be related to either the method used to induce FGR or the very different SC dosing regimes. Most recently, in a third different sheep model in which uterine artery embolization between days 102 and 107 of gestation was used to induce FGR, SC was administered, at the same dose as that used by Satterfield and coworkers, via subcutaneous infusion from the completion of embolization to when pregnancy was terminated at days 132 and 133 of gestation (Oyston et al. 2016). Lamb and placental weights were reduced in the embolized group as compared to control but not when SC was administered: the recovery towards control values with SC was most noticeable in regard to placental weight. Umbilical artery Doppler measurements showed that whilst Resistive Index in the embolized group fell less than controls over gestation, values in the SC-treated group were intermediate between the two. The authors speculate that changes in placental growth with SC were more important than changes in placental efficiency.

In a nutrient restriction rabbit model of FGR (LópezTello et al. 2016), SC administered orally from days 22 to term (days 31) returned crown rump length and biparietal diameter to control (normal nutrition) size, though fetal weight was still as low as in the restricted group. Whilst placental weight was not different between groups, histopathology suggested that SC improved placental vascularity. Interestingly, SC also increased liver to body weight ratio above than that in either nutrient-restricted or control groups. Umbilical artery Doppler measurements in this study showed that nutrient restriction only had an effect on systolic peak velocity, and this variable was similarly above control values in the SC group. However, Doppler measurement of middle cerebral artery indices showed that SC increased resistance index and pulsatility index above the values in the control and nutritionrestricted groups; the authors suggest that this effect of SC could counteract excessive blood flow to the brain and so prevent cerebral oedema.

We found that SC improved fetal growth in two different genetic models of FGR (Stanley et al. 2012b, Dilworth et al. 2013). The catechol-O-methyltransferase knockout (COMT---) mouse was previously reported to have a similar phenotype to pre-eclampsia including hypertension in pregnancy, proteinuria and FGR (Kanasaki et al. 2008). In our study, whilst the COMT-/mouse had a higher systolic pressure than wild-type (WT) mice prior to pregnancy and at day 10, there was no difference later in gestation. Proteinuria (measured as creatinine:albumin ratio) was genotype dependent. Neither variable was affected by SC (administered in drinking water at $0.2 \mathrm{mg} / \mathrm{mL}$ from day 12.5 onwards). However, pup weight at the end of pregnancy was significantly lower in the $\mathrm{COMT}^{-/-}$mouse than in WT mice, and SC partially reversed this effect. Placental weight was higher in the knockout than in WT, and this difference was unaffected by SC. Uterine artery Doppler measurements were not different between COMT-/- and WT and were unaffected by SC. Interestingly, uterine arteries from the COMT- ${ }^{-/}$ mice studied in vitro in the wire myograph did show increased constriction to phenylephrine, as compared to those from WT mice, and this was normalized by SC: these data are similar to those reported by Wareing et al. (2005) for the human myometrial vessels. Umbilical artery Doppler measurements, pulsatility index and resistance index were higher in the COMT-/- vs WT mice and were normalized by SC. These data suggest that the COMT-1mouse as used here is a better model of FGR than of preeclampsia, and that SC is effective in reversing FGR by improving fetoplacental vascular function.

As described above, the P0 mouse provides a model of FGR phenotype with normal placental vascular function and exchange barrier dysfunction. Bearing in mind the assumption, and indeed the evidence discussed here, that SC improves fetal weight in FGR models through an effect on blood flow, we tested the drug in P0 mice with the hypothesis that it would have no effect on fetal growth (Dilworth et al. 2013). Contrary to this, we found that SC, administered similarly to the $\mathrm{COMT}^{-/-}$study, did improve fetal weight in PO fetuses, as compared to untreated P0 animals: $49 \%$ of P0 fetuses were above the 5 th centile of untreated WT weights as compared with 25\% in the untreated P0 group. Placental weight was lower in the untreated P0 vs WT but was increased by SC in the former but not latter. Umbilical artery and vein blood flow velocity measurements were not different between P0 and WT as expected and were unaffected by SC. Measurements of unidirectional methylaminoisobutyric acid (a nonmetabolizable amino acid analogue and substrate of System A) clearance across the placenta suggested that SC increased fetal weight in P0 animals by improving total http://joe.endocrinology-journals.org

DOI: $10.1530 / J O E-17-0185$
() 2017 The author Printed in Great Britain
Published by Bioscientifica Ltd 
placental transfer capacity (combination of small effects on placental size and transporter activity).

The majority of these pre-clinical studies therefore support the effectiveness of SC in treating placental dysfunction in FGR. The dosing regime has been an important factor in effectiveness in in vivo studies, and SC's mode of action seems to be more complex than a simple effect on placental perfusion with effects on placental growth, vascularity and transfer capacity also evident.

Building on the pre-clinical studies SC has been used in clinical case studies (Panda et al. 2014, Choudhary et al. 2016, Sakamoto et al. 2016) and a small case-control trial (von Dadelszen et al. 2011) all of which show that SC can improve outcome of FGR in women. Two prospective randomized trials (Trapani et al. 2016, El-Sayed et al. 2017) have now shown that sildenafil can improve uterine and umbilical artery Doppler indices in FGR suggesting that it does improve uteroplacental blood flow in such pregnancies. These studies all provide the foundation for the 'sildenafil therapy in dismal prognosis early-onset intrauterine growth restriction' (STRIDER) trial, a doubleblind prospective trial of SC which will report in 2017 (Ganzevoort et al. 2014). By providing definitive data on the potential of SC for treating FGR, this trial will also help to determine the credibility of the pre-clinical strategy for discovering treatments of placental dysfunction as described above.

\section{Adenovirus-mediated delivery of vascular endothelial growth factor}

David and coworkers have taken a different, rather more sophisticated approach to increasing uteroplacental blood flow in FGR and pre-eclampsia. They hypothesized that overexpression of VEGF in uterine arteries using an adenovirus vector system would lead to increased uteroplacental blood flow and therefore fetal growth (David et al. 2008). This hypothesis has been tested in a series of pre-clinical studies using sheep and guinea pig models of FGR as well as in vitro studies using the human placenta. First, adenovirus vectors encoding the VEGF-A gene (Ad.VEGF) were injected into the uterine arteries of sheep having normal pregnancies; the data showed that the Ad.VEGF caused a sustained increased in uteroplacental blood flow, whereas vector containing the marker gene beta-galactosidase (Ad.LacZ) had no effect (David et al. 2008, Mehta et al. 2012). Mehta et al. (2012) also reported data suggesting that short-term effects of Ad.VEGF were via upregulation of eNOS, whereas longer- term effects most likely involved increased uterine artery vascularization. They also showed that the human VEGF had not crossed the placenta and that there were no obvious undesirable effects of the adenovirus on mother or fetus. Next, in a sheep model of FGR where overnutrition of adolescent ewes causes reduced uteroplacental blood flow and decreased lamb birth weight near term, Ad.VEGF injection into the uterine artery resulted in improved lamb abdominal circumference, but no significant difference in fetal weight when compared to suitable controls was observed (Carr et al. 2014). However, Ad.VEGF injection in the overnutrition group did lead to fewer lambs with birth weights greater than 2 s.D. below the non-FGR control mean; this is an important finding as clinically small improvements in fetal growth, with subsequent delay in time of delivery, could improve survival and morbidity rates in human FGR. Surprisingly, the authors could not find any effects of Ad.VEGF on uteroplacental blood flow in this study, perhaps due to technical limitations of their measurements. Interestingly, uteroplacental arteries studied in the myograph in vitro did show improved vasodilation and relaxation. However, the study also showed that treatment with Ad.VEGF resulted in upregulation of placental VEGF receptors, suggesting (as with sildenafil as described above) a potentially different, additional, mode of action than that originally hypothesized. More recently (Carr et al. 2016), using the same sheep model of FGR again showed that Ad.VEGF administration increased abdominal circumference at mid gestation as compared to saline-treated controls with a trend towards higher birth weight at term; there were no untoward postnatal effects of the treatment.

Moving to guinea pigs as a more appropriate model of human placentation than sheep, the optimal method for gene delivery to the uterine arteries in guinea pigs was investigated (Mehta et al. 2016). Delivery of adenovirus containing thegeneforbeta-galactosidasewasaccomplished by intravascular injection into the uterine artery or into internal iliac arteries, by external administration whereby vector in PBS was dribbled onto the uterine artery or by external vascular administration of the vector in pluronic gel, a substance that is liquid at room temperature but which becomes a gel at body temperature. The use of pluronic gel was the most successful in every way: success rate of administration, maternal and fetal survival and transduction efficiency with no spread to maternal or fetal tissues. Using this method of administration, Swanson et al. (2016) investigated whether Ad.VEGF would improve fetal growth in an undernutrition model of guinea pig http://joe.endocrinology-journals.org DOI: $10.1530 / J O E-17-0185$
() 2017 The author Printed in Great Britain
Published by Bioscientifica Ltd 
FGR, comparing to similar animals treated with adenovirus encoding a reporter gene, beta-galactosidase (Ad.LacZ). They found a very small (3\%) higher fetal weight in the Ad.VEGF-treated pups at term (60-64 days) with no effect on litter size. There was no effect on placental weight, although placental depth was increased; the weights of fetal liver, brain and lung were increased. VEGF expression was clearly higher in uterine arteries treated with Ad.VEGF than those treated with Ad.LacZ, and ELISA measurements showed that VEGF levels in fetal serum were also higher in the former group, though there were no differences in maternal serum. Importantly, using RT-PCR, adenovirus was only found in the vessels where it had been applied and not in any other maternal or fetal tissue. Uterine arteries, studied in the myograph, constricted similarly when exposed to acetylcholine whether they had been exposed to Ad.VEGF or Ad.LacZ in vitro, but there was a clear difference in the two sets of vessels in terms of acetylcholine-induced vasorelaxation, with Ad.VEGF exposed vessels showing significantly greater relaxation. This may have been related to increased iNOS and eNOS expression in these vessels. There was also evidence that Ad.VEGF increased vascularization in the vessel adventitia, similar to that found in the sheep work, suggesting a longer-term mechanism for its mode of action. Overall, although the very small effect on fetal growth is a concern, this study in an animal model resembling the human shows that Ad.VEGF is a viable treatment for FGR and provides a significant step forward from the sheep work in translating this strategy to the clinic.

Translation of Ad.VEGF therapy to the clinic has been supported by work on the human placenta in vitro to

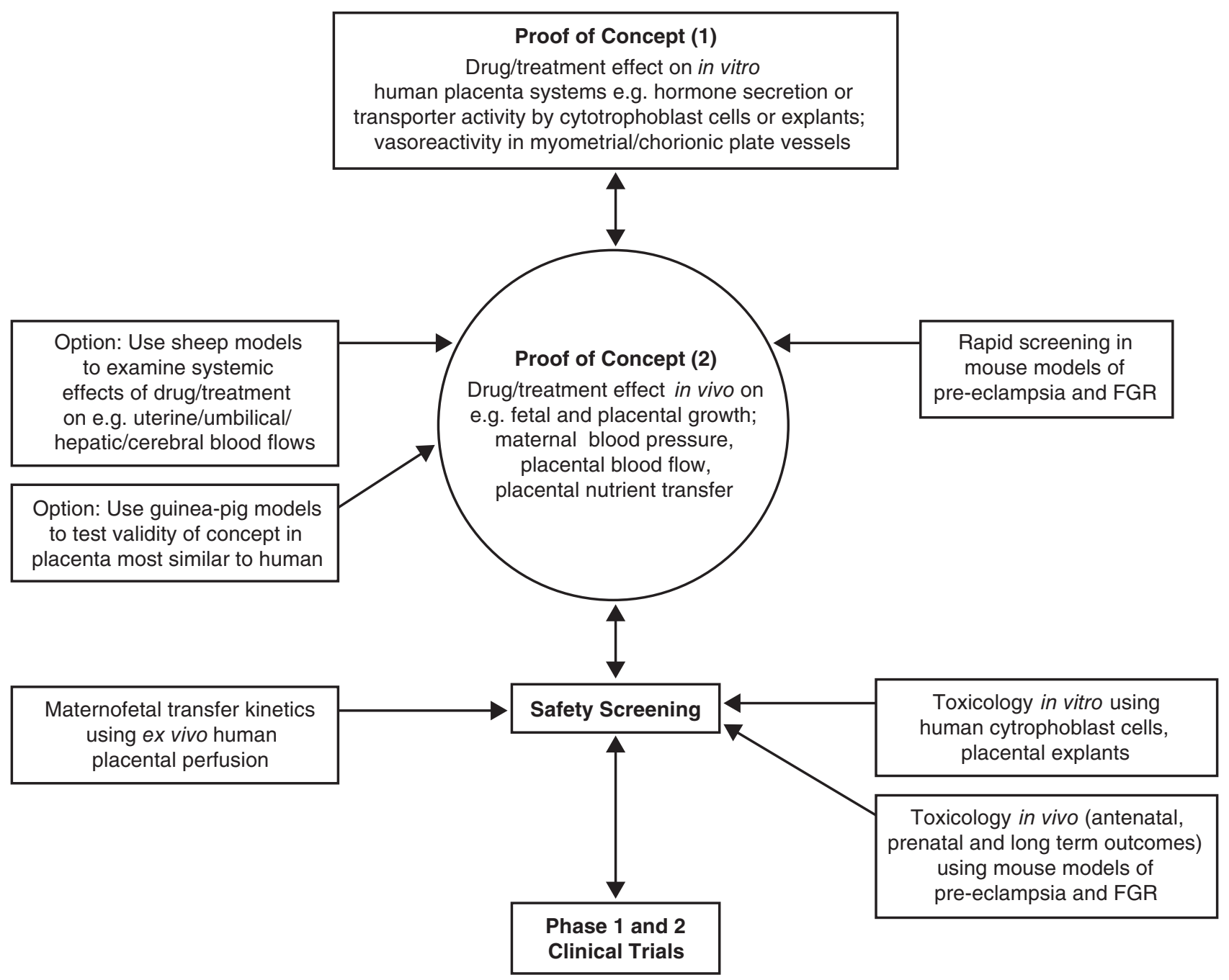

Figure 2

Proposed experimental pathway for taking a potential drug or treatment for placental dysfunction from concept through to early phase clinical trials.

http://joe.endocrinology-journals.org

DOI: 10.1530/JOE-17-0185
(C) 2017 The author Printed in Great Britain
Published by Bioscientifica Ltd 
Table 1 Summary of substances tested as potential treatments for placental dysfunction in pre-clinical studies.

\begin{tabular}{|c|c|c|c|c|c|}
\hline Treatment & $\begin{array}{l}\text { Putative mode of } \\
\text { action }\end{array}$ & Test system (s) & Dosing regime & $\begin{array}{l}\text { Main outcomes of treatment } \\
\text { (compared to appropriate } \\
\text { control) }\end{array}$ & Reference \\
\hline Sildenafil citrate & $\begin{array}{l}\text { Improved } \\
\text { uteroplacental } \\
\text { blood flow }\end{array}$ & See text & See text & See text & See text \\
\hline $\begin{array}{l}\text { Adenovirus vector } \\
\text { with VEGF }\end{array}$ & $\begin{array}{l}\text { Improved } \\
\text { uteroplacental } \\
\text { blood flow }\end{array}$ & See text & See text & See text & See text \\
\hline $\begin{array}{l}\text { Pomegranate } \\
\text { juice (PJ) }\end{array}$ & Antioxidant & $\begin{array}{l}\text { Women having } \\
\text { normal pregnancy/ } \\
\text { placental explants } \\
\text { and primary } \\
\text { cytotrophoblast } \\
\text { cells (cytos) }\end{array}$ & $\begin{array}{l}\text { Women drank } \\
8 \text { oz/day PJ } \\
\text { from } 35 \text { to } \\
38 \text { weeks } \\
\text { gestational age } \\
\text { (ga) to term. } \\
\text { Explants } 1 \% \text { PJ } \\
\text { in medium }\end{array}$ & $\begin{array}{l}\text { Decreased placental } \\
\text { oxidative stress in vivo } \\
\text { and in vitro/decreased } \\
\text { apoptosis/punicalagin key } \\
\text { component of PJ }\end{array}$ & $\begin{array}{l}\text { Chen et al. } \\
(2012,2013)\end{array}$ \\
\hline \multirow[t]{2}{*}{$\begin{array}{l}\text { Tempol } \\
\text { (superoxide } \\
\text { dismutase } \\
\text { mimetic) }\end{array}$} & Antioxidant & $\begin{array}{l}\mathrm{BPH} / 5 \text { mouse model } \\
\text { of pre-eclampsia }\end{array}$ & $\begin{array}{l}1 \mathrm{mmol} / \mathrm{L} \text { from } \\
2 \text { days before } \\
\text { until end } \\
\text { pregnancy }\end{array}$ & $\begin{array}{l}\text { ROS levels reduced/reduced } \\
\text { blood pressure/reduced } \\
\text { proteinuria/fetal and } \\
\text { placental weights } \\
\text { restored towards normal }\end{array}$ & $\begin{array}{l}\text { Hoffmann et al. } \\
\text { (2008) }\end{array}$ \\
\hline & & $\begin{array}{l}\text { eNOS-l- mouse } \\
\text { model of FGR }\end{array}$ & $\begin{array}{l}1 \mathrm{mmol} / \mathrm{L} \\
12.5- \\
18.5 \text { days ga }\end{array}$ & $\begin{array}{l}\text { Fetal weight increased } \\
\text { towards normal/no effect } \\
\text { on placental weight/UtA } \\
\text { end diastolic velocity } \\
\text { restored to normal }\end{array}$ & $\begin{array}{l}\text { Stanley et al. } \\
\quad(2012 a)\end{array}$ \\
\hline Resveratrol & $\begin{array}{l}\text { Antioxidant/ } \\
\text { enhanced NO } \\
\text { bioavailability }\end{array}$ & $\begin{array}{l}\text { COMT-l- and }^{-1} \\
\text { eNOS-l- mouse } \\
\text { models of FGR }\end{array}$ & $\begin{array}{l}4 \mathrm{~g} / \mathrm{kg} \text { in diet } \\
0.5-15.5 \text { days ga }\end{array}$ & $\begin{array}{l}\text { Fetal weight increased } \\
\text { towards normal in } \\
\text { COMT-I- mouse only/no } \\
\text { effect on placental } \\
\text { weight/UtA minimum and } \\
\text { maximum velocity } \\
\text { improved towards normal } \\
\text { in COMT mouse only/no } \\
\text { effects on UmA velocity }\end{array}$ & $\begin{array}{l}\text { Poudel et al. } \\
\text { (2013) }\end{array}$ \\
\hline \multirow[t]{3}{*}{ Melatonin } & $\begin{array}{l}\text { Antioxidant/ } \\
\text { melatonin receptor }\end{array}$ & $\begin{array}{l}\text { Lipopolysaccharide } \\
\text { induced fetal } \\
\text { death and FGR in } \\
\text { mice }\end{array}$ & $\begin{array}{l}4 \mathrm{mg} / \mathrm{kg} \text { orally in } \\
\text { diet throughout } \\
\text { pregnancy }\end{array}$ & $\begin{array}{l}\text { Reduced fetal deaths and } \\
\text { increased fetal weight } \\
\text { towards normal/oxidative } \\
\text { stress reduced }\end{array}$ & $\begin{array}{l}\text { Chen et al. } \\
(2006)\end{array}$ \\
\hline & & $\begin{array}{l}\text { Ischaemia/ } \\
\text { reperfusion } \\
\text { damage to } \\
\text { placenta in rats }\end{array}$ & $\begin{array}{l}20 \mu \mathrm{g} / \mathrm{mL} \text { orally } \\
\text { over course of } \\
\text { I/R experiment } \\
\text { only }\end{array}$ & $\begin{array}{l}\text { Fetal weight restored } \\
\text { towards normal/no effect } \\
\text { on the reduced placental } \\
\text { weight/improved } \\
\text { placental mitochondrial } \\
\text { respiratory control index/ } \\
\text { decreased placental } \\
\text { oxidative stress }\end{array}$ & $\begin{array}{l}\text { Nagai et al. } \\
\quad(2008)\end{array}$ \\
\hline & & $\begin{array}{l}\text { Undernutrition } \\
\text { induced FGR in } \\
\text { rats }\end{array}$ & $\begin{array}{l}5 \mu \mathrm{g} / \mathrm{mL} \text { in } \\
\text { drinking water } \\
15-20 \text { days ga }\end{array}$ & $\begin{array}{l}\text { No effect on fetal weight } \\
\text { but placental weight } \\
\text { reduced so that } \\
\text { fetal:placental weight } \\
\text { ratio restored towards } \\
\text { control values/restored } \\
\text { birth weight towards } \\
\text { control following normal } \\
\text { delivery/upregulation of } \\
\text { placental antioxidant } \\
\text { enzymes }\end{array}$ & $\begin{array}{l}\text { Richter et al. } \\
\text { (2009) }\end{array}$ \\
\hline
\end{tabular}


Table 1 Continued.

\begin{tabular}{|c|c|c|c|c|c|}
\hline Treatment & $\begin{array}{l}\text { Putative mode of } \\
\text { action }\end{array}$ & Test system (s) & Dosing regime & $\begin{array}{l}\text { Main outcomes of treatment } \\
\text { (compared to appropriate } \\
\text { control) }\end{array}$ & Reference \\
\hline & & $\begin{array}{l}\text { Nutrient restriction } \\
\text { induced FGR in } \\
\text { sheep }\end{array}$ & $\begin{array}{l}5 \text { mg supplement } \\
\text { daily in diet } \\
50 \text { days - end of } \\
\text { experiment }\end{array}$ & $\begin{array}{l}\text { Data not easy to interpret: } \\
\text { UmA blood flow } \\
\text { increased irrespective of } \\
\text { nutrient intake/no effect } \\
\text { on UtA blood flow/fetal } \\
\text { weight only increased } \\
\text { when nutrition adequate }\end{array}$ & $\begin{array}{l}\text { Lemley et al. } \\
\text { (2012) }\end{array}$ \\
\hline & & $\begin{array}{l}\text { Nutrient restriction } \\
\text { induced FGR in } \\
\text { sheep }\end{array}$ & As above & $\begin{array}{l}\text { Increased fetal uptake of } \\
\text { branch chained amino } \\
\text { acids in maternal nutrient } \\
\text { restriction }\end{array}$ & $\begin{array}{l}\text { Lemley et al. } \\
\text { (2013) }\end{array}$ \\
\hline & & $\begin{array}{l}\text { Hypobaric hypoxia } \\
\text { (high altitude) } \\
\text { induced FGR in } \\
\text { sheep }\end{array}$ & $\begin{array}{l}10 \mathrm{mg} / \mathrm{kg} / \mathrm{day} \\
\text { orally } 100- \\
150 \text { days ga }\end{array}$ & $\begin{array}{l}\text { Fetal weight and size } \\
\text { further reduced/gestation } \\
\text { increased/maternal } \\
\text { antioxidant capacity } \\
\text { increased }\end{array}$ & $\begin{array}{l}\text { González- } \\
\text { Candia et al. } \\
\text { (2016) }\end{array}$ \\
\hline Sofalcone & $\begin{array}{l}\text { Hemoxygenase-1 } \\
\text { (HO-1) induction; } \\
\text { antioxidant } \\
\text { enzyme }\end{array}$ & $\begin{array}{l}\text { In vitro study: Cytos } \\
\text { and human } \\
\text { umbilical vein } \\
\text { endothelial cells } \\
\text { (HUVECs) }\end{array}$ & $\begin{array}{l}10,20,50 \mu \mathrm{mol} / \mathrm{L} \\
\text { in culture } \\
\text { medium }\end{array}$ & $\begin{array}{l}\text { HO-1 induced in cytos and } \\
\text { HUVECs/decreased sFlt-1 } \\
\text { production from cytos/ } \\
\text { suppressed endothelial } \\
\text { dysfunction in HUVECs }\end{array}$ & $\begin{array}{l}\text { Onda et al. } \\
\text { (2015) }\end{array}$ \\
\hline $\begin{array}{l}\text { Proton pump } \\
\text { inhibitors }\end{array}$ & $\begin{array}{l}\text { HO-1 induction/ } \\
\text { anti-oxidant/ } \\
\text { anti-inflammatory/ } \\
\text { vasodilation }\end{array}$ & $\begin{array}{l}\text { In vitro study: cytos, } \\
\text { HUVECS and } \\
\text { placental explants } \\
\text { from women with } \\
\text { severe early-onset } \\
\text { pre-eclampsia. } \\
\text { In vivo studies: } \\
\text { sFLT-1 } \\
\text { overexpressing } \\
\text { and eNOS-/- mouse } \\
\text { models of } \\
\text { pre-eclampsia/ } \\
\text { hypertension }\end{array}$ & $\begin{array}{l}\text { In vitro: } \\
5-100 \mu \mathrm{mol} / \mathrm{L} \\
\text { lansoprazole, } \\
\text { rabeprazole, } \\
\text { esomerprazole } \\
\text { in culture } \\
\text { medium over } \\
24 \mathrm{~h} . \text { In vivo: } \\
150 \mu \mathrm{g} \\
\text { esomeprazole } \\
\text { sodium i.p. daily }\end{array}$ & $\begin{array}{l}\text { sFLT-1 and sENG secretion } \\
\text { from cytos, explants and } \\
\text { HUVECs reduced/ } \\
\text { endothelial dysfunction } \\
\text { reversed/vasodilated } \\
\text { maternal blood vessels and } \\
\text { decreased BP in mouse } \\
\text { models/increased } \\
\text { antioxidant protein } \\
\text { expression/decreased } \\
\text { secretion of cytokines }\end{array}$ & $\begin{array}{l}\text { Onda et al. } \\
\text { (2017) }\end{array}$ \\
\hline \multirow[t]{3}{*}{ Statins } & $\begin{array}{l}\text { Inhibition of } \\
\text { 3-hydroxy-3- } \\
\text { methylglutaryl- } \\
\text { coenzyme A } \\
\text { reductase (HMG- } \\
\text { CoA) cholesterol } \\
\text { synthesis pathway }\end{array}$ & $\begin{array}{l}\text { Placental explants } \\
\text { from early } \\
\text { pregnancy }\end{array}$ & $\begin{array}{l}\text { Cerivastatin } \\
50 \mathrm{nmol} / \mathrm{L}, \\
\text { pravastatin } \\
250 \mathrm{nmol} / \mathrm{L} \text { in } \\
\text { culture medium } \\
\text { over } 24 \mathrm{~h}\end{array}$ & $\begin{array}{l}\text { Proliferative effect of IGF-I } \\
\text { and IGF-II on cytos } \\
\text { prevented by both statins }\end{array}$ & $\begin{array}{l}\text { Forbes et al. } \\
(2008,2015)\end{array}$ \\
\hline & & $\begin{array}{l}\text { Mouse model of } \\
\text { pre-eclampsia } \\
\text { generated by } \\
\text { lentivral vector- } \\
\text { mediated } \\
\text { overexpression of } \\
\text { sFLT-1 in placenta }\end{array}$ & $\begin{array}{l}\text { Pravastatin } 5 \mu \mathrm{g} / \\
\text { day i.p. from } \\
7.5 \text { day ga } \\
\text { onwards }\end{array}$ & $\begin{array}{l}\text { Blood pressure lowered/ } \\
\text { proteinuria ameliorated/ } \\
\text { sFLT-1 decreased/placental } \\
\text { growth factor (PLGF) } \\
\text { increased }\end{array}$ & $\begin{array}{l}\text { Kumasawa et al. } \\
(2011)\end{array}$ \\
\hline & & $\begin{array}{l}\text { Mouse model of } \\
\text { pre-eclampsia } \\
\text { generated by } \\
\text { injection of } \\
\text { adenovirus } \\
\text { carrying sFLT-1 (not } \\
\text { placenta specific) }\end{array}$ & $\begin{array}{l}\text { Pravastatin } 5 \mathrm{mg} / \\
\text { kg/day from } \\
9 \text { day ga }\end{array}$ & $\begin{array}{l}\text { Placental PLGF and VEGF } \\
\text { upregulated/markers of } \\
\text { hypoxia downregulated }\end{array}$ & Saad et al. (2014) \\
\hline
\end{tabular}

(Continued)

http://joe.endocrinology-journals.org DOI: 10.1530/JOE-17-0185
(C) 2017 The author Printed in Great Britain
Published by Bioscientifica Ltd. 
Table 1 Continued.

\begin{tabular}{|c|c|c|c|c|c|}
\hline Treatment & $\begin{array}{l}\text { Putative mode of } \\
\text { action }\end{array}$ & Test system (s) & Dosing regime & $\begin{array}{l}\text { Main outcomes of treatment } \\
\text { (compared to appropriate } \\
\text { control) }\end{array}$ & Reference \\
\hline & & $\begin{array}{l}\text { In vitro study: cytos, } \\
\text { HUVECS and } \\
\text { placental explants } \\
\text { from women with } \\
\text { severe early-onset } \\
\text { pre-eclampsia. } \\
\text { Clinical study: } 4 \\
\text { women with } \\
\text { pre-eclampsia at } \\
\text { 23-30 weeks ga }\end{array}$ & $\begin{array}{l}\text { In vitro study: } \\
\text { pravastatin in } \\
20,200, \\
2000 \mu \text { mol/L } \\
\text { culture medium. } \\
\text { Clinical study: } \\
\text { women received } \\
40 \text { mg } \\
\text { pravastatin } \\
\text { daily }\end{array}$ & $\begin{array}{l}\text { sFLT-1 secretion from all in } \\
\text { vitro tissues reduced/ } \\
\text { increased sENG } \\
\text { production from HUVECs/ } \\
\text { effect on sFLT-1 mediated } \\
\text { via HMG-CoA pathway/ } \\
\text { clinical study showed data } \\
\text { consistent with disease } \\
\text { stabilization }\end{array}$ & $\begin{array}{l}\text { Brownfoot et al. } \\
\text { (2015a) }\end{array}$ \\
\hline & & $\begin{array}{l}\text { In vitro study similar } \\
\text { to Brownfoot et al. } \\
\text { above }\end{array}$ & $\begin{array}{l}\text { In vitro study: } \\
\text { comparison of } \\
\text { simvastatin, } \\
\text { rosuvastatin and } \\
\text { pravastatin at } \\
0-2000 \mu \mathrm{mol} / \mathrm{L} \\
\text { in culture } \\
\text { medium }\end{array}$ & $\begin{array}{l}\text { Simvastatin most potent } \\
\text { inhibitor of sFLT-1 from } \\
\text { all cells/all increased sENG } \\
\text { secretion/only simvastatin } \\
\text { upregulated HO-1 } \\
\text { expression by placental } \\
\text { explants from pre- } \\
\text { eclampsia }\end{array}$ & $\begin{array}{l}\text { Brownfoot et al. } \\
(2016 b)\end{array}$ \\
\hline & & $\begin{array}{l}\text { Perfused placental } \\
\text { cotyledons and } \\
\text { explants }(21 \% \text { and } \\
\left.1 \% \mathrm{O}_{2}\right) \text { in vitro }\end{array}$ & $\begin{array}{l}0.2 \mu \mathrm{mol} / \mathrm{L} \\
\text { pravastatin } \\
\text { (twice the } \\
\text { serum } \\
\text { concentration } \\
\text { of a } 40 \mathrm{mg} \text { daily } \\
\text { dose') }\end{array}$ & $\begin{array}{l}\text { No effects on sFLT-1 or PIGF } \\
\text { secretion, or fetal } \\
\text { perfusion pressure in } \\
\text { perfused cotyledons/ } \\
\text { increased sFLT-1 secretion } \\
\text { by explants under hypoxic } \\
\text { conditions }\end{array}$ & $\begin{array}{l}\text { Balan et al. } \\
\text { (2017) }\end{array}$ \\
\hline & & $\begin{array}{l}\text { 11ß-Hydroxysteroid } \\
\text { dehydrogenase } \\
\text { type } 2(11 \beta \text {-HSD2) } \\
\text { knockout mouse } \\
\text { model of FGR }\end{array}$ & $\begin{array}{l}20 \mu g / k g \\
\text { pravastatin i.p. } \\
\text { daily from } \\
6 \text { day ga } \\
\text { onwards }\end{array}$ & $\begin{array}{l}\text { Fetal weight and placental } \\
\text { weight increased/UmV } \\
\text { blood velocity } \\
\text { measurements } \\
\text { normalized }\end{array}$ & $\begin{array}{l}\text { Wyrwoll et al. } \\
(2016)\end{array}$ \\
\hline$C-1$ & $\begin{array}{l}\text { Nitric oxide } \\
\text { induction, guanylyl } \\
\text { cyclase activation/ } \\
\text { HIF1 } \alpha \text { inhibition }\end{array}$ & $\begin{array}{l}\text { In vitro study: cytos, } \\
\text { HUVECS and } \\
\text { placental explants } \\
\text { from women with } \\
\text { severe early-onset } \\
\text { pre-eclampsia }\end{array}$ & $\begin{array}{l}0-100 \mu \mathrm{mol} / \mathrm{L} \text { in } \\
\text { culture medium } \\
24-72 \mathrm{~h}\end{array}$ & $\begin{array}{l}\text { sFLT-1 and sENG secretion } \\
\text { from cytos, explants and } \\
\text { HUVECs reduced/ } \\
\text { endothelial dysfunction } \\
\text { reversed/HIF1 } \alpha \text { expression } \\
\text { by explants reduced }\end{array}$ & $\begin{array}{l}\text { Brownfoot et al. } \\
(2015 b)\end{array}$ \\
\hline Metformin & $\begin{array}{l}\text { HIF1 } \alpha \text { inhibition via } \\
\text { blocking of } \\
\text { mitochondrial } \\
\text { electron transport } \\
\text { chain inhibition }\end{array}$ & $\begin{array}{l}\text { In vitro study: cytos, } \\
\text { HUVECS and } \\
\text { placental explants } \\
\text { from women with } \\
\text { severe early-onset } \\
\text { pre-eclampsia }\end{array}$ & $\begin{array}{l}0-1 \mathrm{mmol} / \mathrm{L} \text { in } \\
\text { culture medium } \\
24-72 \mathrm{~h}\end{array}$ & $\begin{array}{l}\text { Similar results to YC-1: } \\
\text { sFLT-1 and sENG secretion } \\
\text { from cytos, explants \& } \\
\text { HUVECs reduced/ } \\
\text { endothelial dysfunction } \\
\text { reversed/HIF1 } \alpha \text { expression } \\
\text { by explants reduced. } \\
\text { Evidence that effect via } \\
\text { mitochondrial electron } \\
\text { transport chain complex } 1\end{array}$ & $\begin{array}{l}\text { Brownfoot et al. } \\
(2016 a)\end{array}$ \\
\hline $\begin{array}{l}\text { [Leu27] insulin- } \\
\text { like growth } \\
\text { factor-II (IGF-II) }\end{array}$ & $\begin{array}{l}\text { IGF-II receptor } \\
\text { antagonist } \\
\text { - increasing IGF-II } \\
\text { bioavailability }\end{array}$ & $\begin{array}{l}\text { eNOS-I- mouse } \\
\text { model of FGR }\end{array}$ & $\begin{array}{l}1 \mathrm{mg} / \mathrm{kg} / \text { day sc } \\
12.5- \\
18.5 \text { day ga }\end{array}$ & $\begin{array}{l}\text { Reduction in number of } \\
\text { FGR }(<5 \text { th centile) pups }\end{array}$ & $\begin{array}{l}\text { Charnock et al. } \\
(2016)\end{array}$ \\
\hline
\end{tabular}

determine potential adverse effects (Brownbill et al. 2014). Ad.VEGF-D at a range of doses had no effect on villous explant integrity and function and similarly had no deleterious effects when perfused through the maternal side of placental cotyledons. There was minimal virus vector tissue uptake, and the vector was rarely detected in fetal venous perfusate, and then only at low titre, suggesting little transplacental transfer.

This combination of large and small animal work together with toxicity testing on the human placenta in vitro has underpinned a Europe wide phase $1 / 2$ a clinical trial investigating the efficacy and safety of adenoviral 
VEGF gene therapy as a treatment for severe early-onset FRG - the EVERREST Trial - which is now in development (Sheppard et al. 2016).

\section{Other substances tested as potential treatments for placental dysfunction in pre-clinical studies}

Table 1 summarizes a range of studies on a number of different potential treatments for placental dysfunction. As can be seen, these have used the wide variety of in vivo and in vitro models described above. Whilst, as already noted, these provide a range of useful data, the diversity of models, the different dosing regimes and different times in gestation when they are applied do not provide the best foundation for translation into early phase clinical trials. Now a number of different groups are working towards treatments for placental dysfunction, and it is clear that an agreed optimal framework for such work would be helpful and indeed essential for reducing the numbers of animals being used and the costs for delivering treatments to the clinic.

As also can be seen from Table 1, a number of different antioxidants have been considered. Of these, melatonin has received the most attention: several, but not all, studies have shown a positive effect on fetal weight in FGR, though in one sheep study melatonin actually worsened the FGR (González-Candia et al. 2016). Nevertheless, melatonin has been tested in clinical trials as a treatment for both pre-eclampsia and FGR (Alers et al. 2013, Hobson et al. 2013): the outcomes of these trials are awaited.

Statins have also received considerable attention. These inhibitors of HMG-CoA reductase in the cholesterol synthesis pathway have reduced sFlt-1 and sENG secretion by the placenta in vitro and in vivo in a number of studies, though there was no effect on sFlt-1 production in one human placental perfusion study (Table 1). Also of note is in vitro work suggesting that statins can prevent IGF-I and II stimulation of cytotrophoblast cell proliferation, with a potential harmful effect on placental growth (Forbes et al. 2008). However, Costantine et al. (2016) have recently reported a small safety and pharmacokinetic trial of pravastatin for the treatment of pre-eclampsia (10 women receiving pravastatin, 10 receiving placebo) and found no adverse effects on mother or baby. Although this was a secondary outcome, pre-eclampsia was reported in 4 of the women receiving placebo but none in those receiving pravastatin; birth weight was similar in the two groups, but placental weight was not reported.
A number of other potential treatments against different placental therapeutic targets are shown in Table 1 with positive results. It is to be hoped that these will stimulate the further work required before clinical trials can be considered. The largely positive reports in Table 1 do raise the possibility that other substances have been tested but, with no effect, the data have not been reported in the published literature. It is particularly important that in a small field like placentology that a forum for the reporting of such negative data is found so as to prevent unnecessary duplication and highlight modes of action not worth pursuing.

\section{Opportunities and challenges}

The work described in this review shows that it is now possible to develop treatments targeted to placental dysfunction. Useful in vitro and in vivo test systems are available and the strategy of repurposing drugs developed for other diseases does provide a pipeline for the placentologist to work with. The outcomes of trials such as STRIDER and EVERREST are eagerly awaited to determine whether this strategy works all the way into the clinic. The challenges cannot be underestimated of course. The need for an agreed framework to pre-clinical studies in this field and for a means of reporting negative results has already been mentioned. The minimization of risk to both mother and fetus of treatments for placental dysfunction has to be the priority; post-natal and later life risks of these treatments must be considered very carefully, both in preclinical work and in early phase clinical trials. The work on targeting therapies using adenoviral vectors is exciting both in terms of improving efficacy of treatments and reducing side effects. Also very promising in this regard is the use of nanoparticles to selectively deliver drug payloads. King and coworkers (King et al. 2016) recently reported that such nanoparticles, decorated with placenta specific homing peptides, can selectively deliver IGF-II to the mouse placenta and, in the P0 mouse model of FGR, improve fetal weight. Targeting drugs to the placenta in this way will hopefully reduce risk and perhaps persuade pharma that it is possible to get involved in developing new drugs with which to treat placental dysfunction.

It is clear from the pathophysiology of placental dysfunction, and indeed from clinical observation that the disease has different phenotypes in different women (Sibley et al. 2005). For example, uteroplacental blood flow reductions may be paramount in some cases of FGR, whereas placental trophoblast dysfunction,

Published by Bioscientifica Ltd. 
with abnormalities in hormone secretion and in maternofetal transport, may be the prime defect in other cases. Such stratification of placental disease, with consequent development of phenotype specific drugs, coupled to selective methods of delivery, such as those described above, will transform the treatment of the dysfunctional placenta.

\section{Footnote}

This article is adapted from work presented at the Aspen/Snowmass Perinatal Biology Symposium, 27-30 August 2016. The meeting was supported in part by the Journal of Endocrinology.

\section{Declaration of interest}

The author declares that there is no conflict of interest that could be perceived as prejudicing the impartiality of this review.

\section{Funding}

The author is very grateful to the funders of work in his laboratory on the topic of this review, primarily, The Wellcome Trust, The Medical Research Council, Tommy's The Baby Charity and an Action Research Endowment Fund.

\section{Acknowledgements}

The author is indebted to Drs Susan Greenwood and Mark Dilworth in Manchester and Prof Michael Nelson at Washington University, St Louis, for their detailed and constructive critiques of this review whilst it was in preparation.

\section{References}

Alers NO, Jenkin G, Miller SL \& Wallace EM 2013 Antenatal melatonin as an antioxidant in human pregnancies complicated by fetal growth restriction - a phase I pilot clinical trial: study protocol. BMJ Open $\mathbf{3}$ e004141. (doi:10.1136/bmjopen-2013-004141)

Balan A, Szaingurten-Solodkin I, Swissa SS, Feinshtein V, Huleihel M, Holcberg G, Dukler D \& Beharier O 2017 The effects of pravastatin on the normal human placenta: Lessons from ex-vivo models. PLoS ONE 12 e0172174. (doi:10.1371/journal.pone.0172174)

Baschat AB \& Galan HL 2017 Intrauteine growth restriction. In Obstetrics: Normal and Problem Pregnancies, edn 7th, pp 737-769. Eds SG Gabbe, JR Niebyl, JL Simpson, MB Landon, HL Galan, ERM Jauniaux, DA Driscoll, V Berghella \& WA Grobman. Philadelphia, PA, USA: Elsevier.

Benton SJ, McCowan LM, Heazell AE, Grynspan D, Hutcheon JA, Senger C, Burke O, Chan Y, Harding JE, Yockell-Lelièvre J, et al. 2016 Placental growth factor as a marker of fetal growth restriction caused by placental dysfunction. Placenta 42 1-8. (doi:10.1016/j. placenta.2016.03.010)

Brien ME, Duval C, Palacios J, Boufaied I, Hudon-Thibeault AA, NadeauVallée M, Vaillancourt C, Sibley CP, Abrahams VM, Jones RL, et al. 2017 Uric acid crystals induce placental inflammation and alter trophoblast function via an IL-1-dependent pathway: implications for fetal growth restriction. Journal of Immunology 198 443-451. (doi:10.4049/jimmunol.1601179)
Brosens I, Pijnenborg R, Vercruysse L \& Romero R 2011 The 'Great Obstetrical Syndromes' are associated with disorders of deep placentation. American Journal of Obstetrics and Gynecology 204 193-201. (doi:10.1016/j.ajog.2010.08.009)

Brownbill P, Edwards D, Jones C, Mahendran D, Owen D, Sibley C, Johnson R, Swanson P \& Nelson DM 1995 Mechanisms of alphafetoprotein transfer in the perfused human placental cotyledon from uncomplicated pregnancy. Journal of Clinical Investigation 96 2220-2226. (doi:10.1172/JCI118277)

Brownbill P, Desforges M, Sebire N, Greenwood SL, Sibley CP \& David AL 2014 Human placental ex vivo studies to support an adenovirusmediated vascular endothelial growth factor (VEGF) gene medicine for the treatment of severe early onset fetal growth restriction (FGR). Human Gene Therapy 25 A60.

Brownfoot FC, Tong S, Hannan NJ, Binder NK, Walker SP, Cannon P, Hastie R, Onda K \& Kaitu'u-Lino TJ 2015a Effects of pravastatin on human placenta, endothelium, and women with severe preeclampsia. Hypertension 66 687-697; discussion 445. (doi:10.1161/ HYPERTENSIONAHA.115.05445

Brownfoot FC, Tong S, Hannan NJ, Hastie R, Cannon P, Tuohey L \& Kaitu'u-Lino TJ $2015 b$ YC-1 reduces placental sFlt-1 and soluble endoglin production and decreases endothelial dysfunction: a possible therapeutic for preeclampsia. Molecular and Cellular Endocrinology 413 202-208. (doi:10.1016/j.mce.2015.06.033)

Brownfoot FC, Hastie R, Hannan NJ, Cannon P, Tuohey L, Parry LJ, Senadheera S, Illanes SE, Kaitu'u-Lino TJ \& Tong S $2016 a$ Metformin as a prevention and treatment for preeclampsia: effects on soluble fms-like tyrosine kinase 1 and soluble endoglin secretion and endothelial dysfunction. American Journal of Obstetrics and Gynecology 214 356.e301-356.e315. (doi:10.1016/j. ajog.2015.12.019)

Brownfoot FC, Tong S, Hannan NJ, Hastie R, Cannon P \& Kaitu'u-Lino TJ $2016 b$ Effects of simvastatin, rosuvastatin and pravastatin on soluble fms-like tyrosine kinase 1 (sFlt-1) and soluble endoglin (sENG) secretion from human umbilical vein endothelial cells, primary trophoblast cells and placenta. BMC Pregnancy and Childbirth 16117. (doi:10.1186/s12884-016-0902-3)

Burton GJ, Sibley CP \& Jauniaux ERM 2017 Placental anatomy and physiology. In Obstetrics: Normal and Problem Pregnancies, edn 7 th pp 2-25. Eds SG Gabbe, JR Niebyl, JL Simpson, MB Landon, HL Galan, ERM Jauniaux, DA Driscoll, V Berghella \& WA Grobman. Philadelphia, PA, USA: Elsevier.

Carr DJ, Wallace JM, Aitken RP, Milne JS, Mehta V, Martin JF, Zachary IC, Peebles DM \& David AL 2014 Uteroplacental adenovirus vascular endothelial growth factor gene therapy increases fetal growth velocity in growth-restricted sheep pregnancies. Human Gene Therapy $\mathbf{2 5}$ 375-384. (doi:10.1089/hum.2013.214)

Carr DJ, Wallace JM, Aitken RP, Milne JS, Martin JF, Zachary IC, Peebles DM \& David AL 2016 Peri- and postnatal effects of prenatal adenoviral VEGF gene therapy in growth-restricted sheep. Biology of Reproduction 94 142. (doi:10.1095/biolreprod.115.133744)

Chappell LC \& David AL 2016 Improving the pipeline for developing and testing pharmacological treatments in pregnancy. PLoS Medicine $\mathbf{1 3}$ e1002161. (doi:10.1371/journal.pmed.1002161)

Charnock JC, Dilworth MR, Aplin JD, Sibley CP, Westwood M \& Crocker IP 2016 The impact of a human IGF-II analog ([Leu27]IGF-II) on fetal growth in a mouse model of fetal growth restriction. American Journal of Physiology: Endocrinology and Metabolism 310 E24-E31. (doi:10.1152/ajpendo.00379.2015)

Chen YH, Xu DX, Wang JP, Wang H, Wei LZ, Sun MF \& Wei W 2006 Melatonin protects against lipopolysaccharide-induced intra-uterine fetal death and growth retardation in mice. Journal of Pineal Research 40 40-47. (doi:10.1111/j.1600-079X.2005.00274.x)

Chen B, Tuuli MG, Longtine MS, Shin JS, Lawrence R, Inder T \& Michael Nelson D 2012 Pomegranate juice and punicalagin attenuate oxidative stress and apoptosis in human placenta and in human http://joe.endocrinology-journals.org

DOI: $10.1530 / J O E-17-0185$
(C) 2017 The author Printed in Great Britain
Published by Bioscientifica Ltd. 
placental trophoblasts. American Journal of Physiology: Endocrinology and Metabolism 302 E1142-E1152. (doi:10.1152/ajpendo.00003.2012)

Chen B, Longtine MS \& Nelson DM 2013 Punicalagin, a polyphenol in pomegranate juice, downregulates p53 and attenuates hypoxiainduced apoptosis in cultured human placental syncytiotrophoblasts. American Journal of Physiology: Endocrinology and Metabolism $\mathbf{3 0 5}$ E1274-E1280. (doi:10.1152/ajpcell.00242.2013)

Choudhary R, Desai K, Parekh H \& Ganla K 2016 Sildenafil citrate for the management of fetal growth restriction and oligohydramnios. International Journal of Women's Health 8 367-372. (doi:10.2147/ijwh. s108370)

Constância M, Hemberger M, Hughes J, Dean W, Ferguson-Smith A, Fundele R, Stewart F, Kelsey G, Fowden A, Sibley C, et al. 2002 Placental-specific IGF-II is a major modulator of placental and fetal growth. Nature 417 945-948. (doi:10.1038/nature00819)

Constância M, Angiolini E, Sandovici I, Smith P, Smith R, Kelsey G, Dean W, Ferguson-Smith A, Sibley CP, Reik W, et al. 2005 Adaptation of nutrient supply to fetal demand in the mouse involves interaction between the Igf2 gene and placental transporter systems. PNAS 102 19219-19224. (doi:10.1073/pnas.0504468103)

Costa MA 2016 The endocrine function of human placenta: an overview. Reproductive BioMedicine Online 32 14-43. (doi:10.1016/j. rbmo.2015.10.005)

Costantine MM, Cleary K, Hebert MF, Ahmed MS, Brown LM, Ren Z, Easterling TR, Haas DM, Haneline LS, Caritis SN, et al. 2016 Safety and pharmacokinetics of pravastatin used for the prevention of preeclampsia in high-risk pregnant women: a pilot randomized controlled trial. American Journal of Obstetrics and Gynecology 214720 e701-720.e717. (doi:10.1016/j.ajog.2015.12.038)

David AL, Torondel B, Zachary I, Wigley V, Abi-Nader K, Nader KA, Mehta V, Buckley SM, Cook T, Boyd M, et al. 2008 Local delivery of VEGF adenovirus to the uterine artery increases vasorelaxation and uterine blood flow in the pregnant sheep. Gene Therapy 15 1344-1350. (doi:10.1038/gt.2008.102)

Desforges M \& Sibley CP 2010 Placental nutrient supply and fetal growth. International Journal of Developmental Biology 54 377-390. (doi:10.1387/ijdb.082765md)

Dilworth MR \& Sibley CP 2013 Review: transport across the placenta of mice and women. Placenta 34 (Supplement) S34-S39. (doi:10.1016/j. placenta.2012.10.011)

Dilworth MR, Kusinski LC, Cowley E, Ward BS, Husain SM, Constância M, Sibley CP \& Glazier JD 2010 Placental-specific Igf2 knockout mice exhibit hypocalcemia and adaptive changes in placental calcium transport. PNAS 107 3894-3899. (doi:10.1073/pnas.0911710107)

Dilworth MR, Kusinski LC, Baker BC, Renshall LJ, Greenwood SL, Sibley CP \& Wareing M 2011 Defining fetal growth restriction in mice: a standardized and clinically relevant approach. Placenta 32 914-916. (doi:10.1016/j.placenta.2011.08.007)

Dilworth MR, Andersson I, Renshall LJ, Cowley E, Baker P, Greenwood S, Sibley CP \& Wareing M 2013 Sildenafil citrate increases fetal weight in a mouse model of fetal growth restriction with a normal vascular phenotype. PLOS ONE 8 e77748. (doi:10.1371/journal.pone.0077748)

Doridot L, Passet B, Méhats C, Rigourd V, Barbaux S, Ducat A, Mondon F, Vilotte M, Castille J, Breuiller-Fouché M, et al. 2013 Preeclampsia-like symptoms induced in mice by fetoplacental expression of STOX1 are reversed by aspirin treatment. Hypertension 61 662-668. (doi:10.1161/ HYPERTENSIONAHA.111.202994)

Duley L 2009 The global impact of pre-eclampsia and eclampsia. Seminars in Perinatology 33 130-137. (doi:10.1053/j.semperi.2009.02.010)

El-Sayed MA, Saleh SA, Maher MA \& Khidre AM 2017 Utero-placental perfusion Doppler indices in growth restricted fetuses: effect of sildenafil citrate. Journal of Maternal-Fetal and Neonatal Medicine 1-6. (doi:10.1080/14767058.2017.1306509)

Erlandsson L, Nääv A, Hennessy A, Vaiman D, Gram M, Åkerström B \& Hansson SR 2016 Inventory of novel animal models addressing etiology of preeclampsia in the development of new therapeutic/ intervention opportunities. American Journal of Reproductive Immunology 75 402-410. (doi:10.1111/aji.12460)

Fisk NM \& Atun R 2008 Market failure and the poverty of new drugs in maternal health. PLoS Medicine 5 e22. (doi:10.1371/journal. pmed.0050022)

Flenady V, Koopmans L, Middleton P, Frøen JF, Smith GC, Gibbons K, Coory M, Gordon A, Ellwood D, McIntyre HD, et al. 2011 Major risk factors for stillbirth in high-income countries: a systematic review and meta-analysis. Lancet 377 1331-1340. (doi:10.1016/S01406736(10)62233-7)

Forbes K, Hurst LM, Aplin JD, Westwood M \& Gibson JM 2008 Statins are detrimental to human placental development and function; use of statins during early pregnancy is inadvisable. Journal of Cellular and Molecular Medicine 12 2295-2296. (doi:10.1111/j.15824934.2008.00466.x)

Forbes K, Shah VK, Siddals K, Gibson JM, Aplin JD \& Westwood M 2015 Statins inhibit insulin-like growth factor action in first trimester placenta by altering insulin-like growth factor 1 receptor glycosylation. Molecular Human Reproduction 21 105-114. (doi:10.1093/molehr/gau093)

Franks ME, Macpherson GR \& Figg WD 2004 Thalidomide. Lancet 363 1802-1811. (doi:10.1016/S0140-6736(04)16308-3)

Ganzevoort W, Alfirevic Z, von Dadelszen P, Kenny L, Papageorghiou A, van Wassenaer-Leemhuis A, Gluud C, Mol BW \& Baker PN 2014 STRIDER: sildenafil therapy in dismal prognosis early-onset intrauterine growth restriction - a protocol for a systematic review with individual participant data and aggregate data meta-analysis and trial sequential analysis. Systematic Reviews 3 23. (doi:10.1186/2046-4053-3-23)

González-Candia A, Veliz M, Araya C, Quezada S, Ebensperger G, SerónFerré M, Reyes RV, Llanos AJ \& Herrera EA 2016 Potential adverse effects of antenatal melatonin as a treatment for intrauterine growth restriction: findings in pregnant sheep. American Journal of Obstetrics and Gynecology 215 245.e241-245.e247. (doi:10.1016/ j.ajog.2016.02.040)

Greenwood SL \& Sibley CP 2006 In vitro methods for studying human placental amino acid transport:placental villous fragments. In Placenta and Trophoblast: Methods and Protocols, pp 253-264. Eds MJ Soares \& JS Hunt. New Jersey, NJ, USA: Humana Press.

Heazell AE, Siassakos D, Blencowe H, Burden C, Bhutta ZA, Cacciatore J, Dang N, Das J, Flenady V, Gold KJ, et al. 2016 Stillbirths: economic and psychosocial consequences. Lancet 387 604-616. (doi:10.1016/ S0140-6736(15)00836-3)

Hefler LA, Reyes CA, O'Brien WE \& Gregg AR 2001 Perinatal development of endothelial nitric oxide synthase-deficient mice. Biology of Reproduction 64 666-673. (doi:10.1095/biolreprod64.2.666)

Hobson SR, Lim R, Gardiner EE, Alers NO \& Wallace EM 2013 Phase I pilot clinical trial of antenatal maternally administered melatonin to decrease the level of oxidative stress in human pregnancies affected by pre-eclampsia (PAMPR): study protocol. BMJ Open 3 e003788. (doi:10.1136/bmjopen-2013-003788)

Hoffmann DS, Weydert CJ, Lazartigues E, Kutschke WJ, Kienzle MF, Leach JE, Sharma JA, Sharma RV \& Davisson RL 2008 Chronic tempol prevents hypertension, proteinuria, and poor feto-placental outcomes in BPH/5 mouse model of preeclampsia. Hypertension 51 1058-1065. (doi:10.1161/HYPERTENSIONAHA.107.107219)

Huang PL, Huang Z, Mashimo H, Bloch KD, Moskowitz MA, Bevan JA \& Fishman MC 1995 Hypertension in mice lacking the gene for endothelial nitric oxide synthase. Nature 377 239-242. (doi:10.1038/377239a0)

Jones S, Bischof H, Lang I, Desoye G, Greenwood SL, Johnstone ED, Wareing M, Sibley CP \& Brownbill P 2015 Dysregulated flowmediated vasodilatation in the human placenta in fetal growth restriction. Journal of Physiology 593 3077-3092. (doi:10.1113/ JP270495)

Kanasaki K, Palmsten K, Sugimoto H, Ahmad S, Hamano Y, Xie L, Parry S, Augustin HG, Gattone VH, Folkman J, et al. 2008 Deficiency

Published by Bioscientifica Ltd. 
in catechol-O-methyltransferase and 2-methoxyoestradiol is associated with pre-eclampsia. Nature 453 1117-1121. (doi:10.1038/ nature06951)

King A, Ndifon C, Lui S, Widdows K, Kotamraju VR, Agemy L, Teesalu T, Glazier JD, Cellesi F, Tirelli N, et al. 2016 Tumor-homing peptides as tools for targeted delivery of payloads to the placenta. Science Advances 2 e1600349. (doi:10.1126/sciadv.1600349)

Kliman HJ, Nestler JE, Sermasi E, Sanger JM \& Strauss JF 1986 Purification, characterization, and in vitro differentiation of cytotrophoblasts from human term placentae. Endocrinology 118 1567-1582. (doi:10.1210/ endo-118-4-1567)

Kulandavelu S, Whiteley KJ, Qu D, Mu J, Bainbridge SA \& Adamson SL 2012 Endothelial nitric oxide synthase deficiency reduces uterine blood flow, spiral artery elongation, and placental oxygenation in pregnant mice. Hypertension 60 231-238. (doi:10.1161/ HYPERTENSIONAHA.111.187559)

Kulandavelu S, Whiteley KJ, Bainbridge SA, Qu D \& Adamson SL 2013 Endothelial NO synthase augments fetoplacental blood flow, placental vascularization, and fetal growth in mice. Hypertension $\mathbf{6 1}$ 259-266. (doi:10.1161/HYPERTENSIONAHA.112.201996)

Kumasawa K, Ikawa M, Kidoya H, Hasuwa H, Saito-Fujita T, Morioka Y, Takakura N, Kimura T \& Okabe M 2011 Pravastatin induces placental growth factor (PGF) and ameliorates preeclampsia in a mouse model. PNAS 108 1451-1455. (doi:10.1073/ pnas.1011293108)

Kusinski LC, Dilworth MR, Baker PN, Sibley CP, Wareing M \& Glazier JD 2011 System A activity and vascular function in the placentalspecific Igf2 knockout mouse. Placenta 32 871-876. (doi:10.1016/j. placenta.2011.07.086)

Kusinski LC, Stanley JL, Dilworth MR, Hirt CJ, Andersson IJ, Renshall LJ, Baker BC, Baker PN, Sibley CP, Wareing M, et al. 2012 eNOS knockout mouse as a model of fetal growth restriction with an impaired uterine artery function and placental transport phenotype. American Journal of Physiology: Regulatory, Integrative and Comparative Physiology $\mathbf{3 0 3}$ R86-R93. (doi:10.1152/ajpregu.00600.2011)

Lemley CO, Meyer AM, Camacho LE, Neville TL, Newman DJ, Caton JS \& Vonnahme KA 2012 Melatonin supplementation alters uteroplacental hemodynamics and fetal development in an ovine model of intrauterine growth restriction. American Journal of Physiology: Regulatory, Integrative and Comparative Physiology 302 R454-R467. (doi:10.1152/ajpregu.00407.2011)

Lemley CO, Camacho LE \& Vonnahme KA 2013 Uterine infusion of melatonin or melatonin receptor antagonist alters ovine feto-placental hemodynamics during midgestation. Biology of Reproduction $\mathbf{8 9} 40$.

López-Tello J, Arias-Álvarez M, Jiménez-Martínez M, Barbero-Fernández A, García-García RM, Rodríguez M, Lorenzo PL, Torres-Rovira L, Astiz S, González-Bulnes A, et al. 2016 The effects of sildenafil citrate on feto? Placental development and haemodynamics in a rabbit model of intrauterine growth restriction. Reproduction, Fertility, and Development [in press]. (doi:10.1071/RD1533)

McCarthy FP, Kingdom JC, Kenny LC \& Walsh SK 2011 Animal models of preeclampsia; uses and limitations. Placenta 32 413-419. (doi:10.1016/j.placenta.2011.03.010)

Mehta V, Abi-Nader KN, Peebles DM, Benjamin E, Wigley V, Torondel B, Filippi E, Shaw SW, Boyd M, Martin J, et al. 2012 Long-term increase in uterine blood flow is achieved by local overexpression of VEGF-A(165) in the uterine arteries of pregnant sheep. Gene Therapy 19 925-935. (doi:10.1038/gt.2011.158)

Mehta V, Ofir K, Swanson A, Kloczko E, Boyd M, Barker H, AvdicBelltheus A, Martin J, Zachary I, Peebles D, et al. 2016 Gene targeting to the uteroplacental circulation of pregnant guinea pigs. Reproductive Sciences 23 1087-1095. (doi:10.1177/1933719116630411)

Miller SL, Loose JM, Jenkin G \& Wallace EM 2009 The effects of sildenafil citrate (Viagra) on uterine blood flow and well being in the intrauterine growth-restricted fetus. American Journal of Obstetrics and Gynecology 200 102.e101-102.e107.
Nadeau-Vallée M, Obari D, Palacios J, Brien M, Duval C, Chemtob S \& Girard S 2016 Sterile inflammation and pregnancy complications: a review. Reproduction 152 R277-R292.

Nagai R, Watanabe K, Wakatsuki A, Hamada F, Shinohara K, Hayashi Y, Imamura R \& Fukaya T 2008 Melatonin preserves fetal growth in rats by protecting against ischemia/reperfusion-induced oxidative/ nitrosative mitochondrial damage in the placenta. Journal of Pineal Research 45 271-276. (doi:10.1111/j.1600-079X.2008.00586.x)

Nassar AH, Masrouha KZ, Itani H, Nader KA \& Usta IM 2012 Effects of sildenafil in $\mathrm{N} \omega$-nitro-L-arginine methyl ester-induced intrauterine growth restriction in a rat model. American Journal of Perinatology 29 429-434. (doi:10.1055/s-0032-1304823)

Onda K, Tong S, Nakahara A, Kondo M, Monchusho H, Hirano T, Kaitu'u-Lino T, Beard S, Binder N, Tuohey L, et al. 2015 Sofalcone upregulates the nuclear factor (erythroid-derived 2)-like 2 /heme oxygenase-1 pathway, reduces soluble fms-like tyrosine kinase-1, and quenches endothelial dysfunction: potential therapeutic for preeclampsia. Hypertension 65 855-862. (doi:10.1161/ HYPERTENSIONAHA.114.04781)

Onda K, Tong S, Beard S, Binder N, Muto M, Senadheera SN, Parry L, Dilworth M, Renshall L, Brownfoot F, et al. 2017 Proton pump inhibitors decrease soluble fms-like tyrosine kinase- 1 and soluble endoglin secretion, decrease hypertension, and rescue endothelial dysfunction. Hypertension 69 457-468. (doi:10.1161/ HYPERTENSIONAHA.116.08408)

Oyston C, Stanley JL, Oliver MH, Bloomfield FH \& Baker PN 2016 Maternal administration of sildenafil citrate alters fetal and placental growth and fetal-placental vascular resistance in the growthrestricted ovine fetus. Hypertension 68 760-767. (doi:10.1161/ HYPERTENSIONAHA.116.07662)

Panda S, Das A \& Md Nowroz H 2014 Sildenafil citrate in fetal growth restriction. Journal of Reproduction and Infertility 15 168-169.

Panitchob N, Widdows KL, Crocker IP, Johnstone ED, Please CP, Sibley CP, Glazier JD, Lewis RM \& Sengers BG 2016 Computational modelling of placental amino acid transfer as an integrated system. Biochimica et Biophysica Acta 1858 1451-1461. (doi:10.1016/j. bbamem.2016.03.028)

Poudel R, Stanley JL, Rueda-Clausen CF, Andersson IJ, Sibley CP, Davidge ST \& Baker PN 2013 Effects of resveratrol in pregnancy using murine models with reduced blood supply to the uterus. PLOS ONE 8 e64401. (doi:10.1371/journal.pone.0064401)

Powe CE, Levine RJ \& Karumanchi SA 2011 Preeclampsia, a disease of the maternal endothelium: the role of antiangiogenic factors and implications for later cardiovascular disease. Circulation 123 2856-2869. (doi:10.1161/CIRCULATIONAHA.109.853127)

Richter HG, Hansell JA, Raut S \& Giussani DA 2009 Melatonin improves placental efficiency and birth weight and increases the placental expression of antioxidant enzymes in undernourished pregnancy. Journal of Pineal Research 46 357-364. (doi:10.1111/j.1600079X.2009.00671.x)

Saad AF, Kechichian T, Yin H, Sbrana E, Longo M, Wen M, Tamayo E, Hankins GD, Saade GR \& Costantine MM 2014 Effects of pravastatin on angiogenic and placental hypoxic imbalance in a mouse model of preeclampsia. Reproductive Sciences 21 138-145. (doi:10.1177/1933719113492207)

Sakamoto M, Osato K, Kubo M, Nii M, Tanaka H, Murabayashi N, Umekawa T, Kamimoto Y \& Ikeda T 2016 Early-onset fetal growth restriction treated with the long-acting phosphodiesterase-5 inhibitor tadalafil: a case report. Journal of Medical Case Reports 10317. (doi:10.1186/s13256-016-1098-x)

Satterfield MC, Bazer FW, Spencer TE \& Wu G 2010 Sildenafil citrate treatment enhances amino acid availability in the conceptus and fetal growth in an ovine model of intrauterine growth restriction. Journal of Nutrition 140 251-258. (doi:10.3945/jn.109.114678)

Schneider H, Panigel M \& Dancis J 1972 Transfer across the perfused human placenta of antipyrine, sodium and leucine. American 
Journal of Obstetrics and Gynecology 114 822-828. (doi:10.1016/00029378(72)90909-X)

Sferruzzi-Perri AN \& Camm EJ 2016 The programming power of the placenta. Frontiers in Physiology 7 33. (doi:10.3389/fphys.2016.00033)

Sheppard M, Spencer RN, Ashcroft R, David AL \& Consortium E 2016 Ethics and social acceptability of a proposed clinical trial using maternal gene therapy to treat severe early-onset fetal growth restriction. Ultrasound in Obstetrics and Gynecology 47 484-491. (doi:10.1002/uog.15880)

Sibley CP, Coan PM, Ferguson-Smith AC, Dean W, Hughes J, Smith P, Reik W, Burton GJ, Fowden AL \& Constância M 2004 Placental-specific insulin-like growth factor 2 (Igf2) regulates the diffusional exchange characteristics of the mouse placenta. PNAS 101 8204-8208. (doi:10.1073/pnas.0402508101)

Sibley CP, Turner MA, Cetin I, Ayuk P, Boyd CA, D'Souza SW, Glazier JD, Greenwood SL, Jansson T \& Powell T 2005 Placental phenotypes of intrauterine growth. Pediatric Research 58 827-832. (doi:10.1203/01. PDR.0000181381.82856.23)

Simán CM, Sibley CP, Jones CJ, Turner MA \& Greenwood SL 2001 The functional regeneration of syncytiotrophoblast in cultured explants of term placenta. American Journal of Physiology: Regulatory, Integrative and Comparative Physiology 280 R1116-R1122.

Stanley JL, Andersson IJ, Hirt CJ, Moore L, Dilworth MR, Chade AR, Sibley CP, Davidge ST \& Baker PN 2012a Effect of the anti-oxidant tempol on fetal growth in a mouse model of fetal growth restriction. Biology of Reproduction 87 21-28. (doi:10.1095/biolreprod.111.096198)

Stanley JL, Andersson IJ, Poudel R, Rueda-Clausen CF, Sibley CP, Davidge ST \& Baker PN 2012b Sildenafil citrate rescues fetal growth in the catechol-O-methyl transferase knockout mouse model. Hypertension 59 1021-1028. (doi:10.1161/HYPERTENSIONAHA.111.186270)

Swanson AM \& David AL 2015 Animal models of fetal growth restriction: considerations for translational medicine. Placenta 36 623-630. (doi:10.1016/j.placenta.2015.03.003)

Swanson AM, Rossi CA, Ofir K, Mehta V, Boyd M, Barker H, Ledwozyw A, Vaughan O, Martin J, Zachary I, et al. 2016 Maternal therapy with Ad.VEGF-A165 increases fetal weight at term in a guinea-pig model of fetal growth restriction. Human Gene Therapy 27 997-1007. (doi:10.1089/hum.2016.046)
Trapani A, Gonçalves LF, Trapani TF, Franco MJ, Galluzzo RN \& Pires MM 2016 Comparison between transdermal nitroglycerin and sildenafil citrate in intrauterine growth restriction: effects on uterine, umbilical and fetal middle cerebral artery pulsatility indices. Ultrasound in Obstetrics and Gynecology 48 61-65. (doi:10.1002/uog.15673)

Villanueva-García D, Mota-Rojas D, Hernández-González R, SánchezAparicio P, Alonso-Spilsbury M, Trujillo-Ortega ME, Necoechea RR \& Nava-Ocampo AA 2007 A systematic review of experimental and clinical studies of sildenafil citrate for intrauterine growth restriction and pre-term labour. Journal of Obstetrics and Gynaecology $\mathbf{2 7}$ 255-259. (doi:10.1080/01443610701194978)

von Dadelszen P, Dwinnell S, Magee LA, Carleton BC, Gruslin A, Lee B, Lim KI, Liston RM, Miller SP, Rurak D, et al. 2011 Sildenafil citrate therapy for severe early-onset intrauterine growth restriction. BJOG 118 624-628. (doi:10.1111/j.1471-0528.2010.02879.x)

Wareing M, Crocker IP, Warren AY, Taggart MJ \& Baker PN 2002 Characterization of small arteries isolated from the human placental chorionic plate. Placenta 23 400-409. (doi:10.1053/plac.2002.0825)

Wareing M, Myers JE, O'hara M, Kenny LC, Warren AY, Taggart MJ, Skillern L, Machin I \& Baker PN 2004 Effects of a phosphodiesterase-5 (PDE5) inhibitor on endothelium-dependent relaxation of myometrial small arteries. American Journal of Obstetrics and Gynecology 190 1283-1290. (doi:10.1016/j.ajog.2003.12.024)

Wareing M, Myers JE, O'Hara M \& Baker PN 2005 Sildenafil citrate (Viagra) enhances vasodilatation in fetal growth restriction. Journal of Clinical Endocrinology and Metabolism 90 2550-2555. (doi:10.1210/ jc.2004-1831)

Widdows KL, Panitchob N, Crocker IP, Please CP, Hanson MA, Sibley CP, Johnstone ED, Sengers BG, Lewis RM \& Glazier JD 2015 Integration of computational modeling with membrane transport studies reveals new insights into amino acid exchange transport mechanisms. FASEB Journal 29 2583-2594. (doi:10.1096/fj.14267773)

Wyrwoll CS, Noble J, Thomson A, Tesic D, Miller MR, Rog-Zielinska EA, Moran CM, Seckl JR, Chapman KE \& Holmes MC 2016 Pravastatin ameliorates placental vascular defects, fetal growth, and cardiac function in a model of glucocorticoid excess. PNAS 113 6265-6270. (doi:10.1073/pnas.1520356113)

Received in final form 25 April 2017

Accepted 3 May 2017
(C) 2017 The author Printed in Great Britain
Published by Bioscientifica Ltd 